\title{
Perkembangan Aspek Sosial-Emosional dan Kegiatan Pembelajaran yang Sesuai untuk Anak Usia 4-6 Tahun
}

\author{
Ina Maria \\ Institut Pesantren K.H. Abdul Chalim Mojokerto \\ inamaria708@gmail.com \\ Eka Rizki Amalia \\ Institut Pesantren K.H. Abdul Chalim Mojokerto \\ ekarizkiamalia2104@gmail.com
}

\begin{abstract}
Social-emotional development is one of the most important developmental aspects for every child because it is one of the determinants of his success in the future. Early age is a golden age for every aspect of development, including social-emotional aspects. Therefore, the process of children's development must always be considered in order to run optimally. This is a library research with the purpose to explain; 1) the theory of social-emotional development, 2) the characteristics of social-emotional development of children aged 4-6 years, 3) resilience in children, and 4) learning activities suitable for children aged 4-6 years in optimizing their social-emotional development. Explanation of the four main topics discussed above will greatly help parents and teachers in understanding and improving children's social emotional abilities.
\end{abstract}

Keywords: Social-Emotional Development, Resilience, Appropriate Learning Activities

\begin{abstract}
Abstrak
Perkembangan sosial emosional merupakan salah satu aspek perkembangan yang sangat penting bagi setiap anak karena merupakan salah satu faktor penentu kesuksesannya di masa depan. Masa usia dini merupakan masa keemasan untuk setiap aspek perkembangan, termasuk aspek sosial emosional. Maka dari itu, proses tumbuh kembang anak harus selalu diperhatikan agar berjalan dengan optimal. Penelitian ini adalah penelitian kajian pustaka (library research). Adapun tujuan dari studi ini adalah untuk menjelaskan; 1) teori perkembangan sosial emosional, 2) karakteristik perkembangan sosial emosional anak usia 4-6 tahun, 3) resiliensi pada anak, dan 4) kegiatan pembelajaran yang sesuai untuk anak usia 4-6 tahun dalam mengoptimalkan perkembangan sosial emosionalnya. Penjelasan mengenai empat pokok pembahasan di atas akan sangat mambantu orangtua dan guru dalam memahami dan meningkatkan kemampuan sosial emosional anak.
\end{abstract}

Kata kunci: Perkembangan sosial emosional, resiliensi, pembelajaran yang sesuai.

\section{Pendahuluan}

Menurut UU Sisdiknas 2003 anak usia dini adalah anak yang berada pada usia 0-6 tahun dan antara 0-8 tahun menurut para pakar Pendidikan. Pada masa ini anak mengalami 
pertumbuhan serta perkembangan sangat pesat yang tidak akan tergantikan di masa mendatang sehingga masa ini disebut sebagai masa golden age. Masa golden age ini sangat berpengaruh pada tahap tumbuh kembang selanjutnya. Masa ini juga hanya berlangsung satu kali dalam seumur hidup setiap individu (Trianto, 2011: 7). Maka dari itu proses tumbuh kembang pada masa ini harus sangat diperhatikan oleh guru maupun orangtua.

Selain itu, masa usia dini ini disebut juga sebagai periode sensitif (critical period). Dimana pada periode ini kematangan fungsi fisik dan psikis anak sudah siap untuk merespon stimulasi yang diberikan oleh lingkungan (Musringati, 2017: 1). Oleh karena itu, seluruh kebutuhan tumbuh kembang anak harus dipenuhi dengan baik agar tumbuh kembang anak berlangsung dengan optimal. Kebutuhan tumbuh kembang itu meliputi asupan gizi, pemberian stimulasi dan intervensi, serta lingkungan yang mendukung. Jika salah satu atau sebagian kebutuhan itu tidak terpenuhi, maka akan menyebabkan terganggu atau kurang optimalnya tumbuh kembang anak. Misalkan, seorang anak yang diasuh dan distimulasi dengan baik, namun asupan gizinya tidak terpenuhi dengan baik maka tumbuh kembang anak itu terhambat (Anwar \& Ahmad, 2016: 8-9).

Pendidikan yang diberikan pada masa usia dini ini sangat penting karena pada masa ini potensi kecerdasan dan karakter dasar seorang individu dibentuk (Trianto, 2011: 5). Pendidikan yang diberikanpun harus berdasarkan pada kebutuhan tumbuh kembang anak. Selain itu juga, pendidikan harus dilaksanakan dengan dukungan penuh dari orangtua, guru, masyarakat, dan lingkungan. Pendidik (orangtua dan guru) harus mampu menciptakan suasana belajar yang aman dan menyenangkan bagi anak (Aqib, 2009: 9). Maka dari itu, pada masa ini anak harus mendapatkan pendidikan yang optimal agar pertumbuhan dan perkembangannya berjalan dengan baik hingga ia dewasa.

Anak-anak memiliki beberapa aspek perkembangan, salah satunya adalah aspek sosial-emosional. Meski sosial dan emosional adalah dua kata yang memiliki makna yang berbeda, tetapi sebenarnya aspek sosial emosional ini tidak dapat dipisahkan. Hal ini dikarenakan kedua aspek ini saling bersinggungan satu sama lain (Mulyani, 2014: 145). Perkembangan sosial emosional ini bertujuan agar anak memiliki keprcayaan diri, kemampuan bersosialisasi, dan kemampuan mengendalikan emosi (Musringati, 2017: 1). Optimalisasi perkembangan sosial emosional ini ditentukan oleh kualitas kerjasama antara orangtua, guru, dan lingkungan (Wahyuni, Syukri, \& Miranda, 2015:2).

Untuk optimalisasi perkembangan sosial emosional ini dapat dilakukan dengan mulai mengajak anak mengenal dirinya sendiri dan lingkungan. Proses pengenalan ini 
dapat berupa interaksi anak dengan keluarga yang akan membuat anak belajar membangun konsep diri. Juga dapat dengan cara bermain bersama teman sebaya yang akan melatih dan meningkatkan kemampuan sosialisasi anak (Musringati, 2017: 1-2). Kemudian, orangtua maupun guru dapat mengembangkan aspek ini melalui beberapa keteladanan (Nurjannah, 2017: 52), seperti beribadah, saling interaksi dengan orang lain, bekerja sama, berpakaian, cara belajar, gaya hidup, dan lainnya.

Semakin sering perilaku sosial emosional anak dilatih, maka kemampuan problem solving-nya pun akan semakin baik (Wahyuni, dkk, 2015:2). Maka dari itu orangtua maupun guru harus sesering mungkin mengajak anak bermain permainan yang dapat melatih kemapuan sosial emosional anak. Orangtua dan guru dapat melakukannya melalui metode bercerita, bermain peran, dan sebagainya. Ketika orangtua maupun guru memberikan stimulasi dan intervensi yang baik serta didukung oleh lingkungan yang baik pula, maka kemampuan sosial emosional anak akan berkembang dengan optimal.

Perkembangan sosial diartikan sebagai kemampuan anak dalam berinteraksi dengan teman sebaya, orang dewasa, dan masyarakat luas agar dapat meyesuaikan diri dengan baik sesuai dengan harapan bangsa dan negara (Mayar, 2013: 459). Perkembangan sosial ini mengikuti suatu pola perilaku sosial. Dimana pola ini berlaku pada semua anak yang berada dalam satu kelompok budaya. Perkembangan ini dimulai sejak bayi mampu berinteraksi dengan keluarganya. Pengalaman sosial yang dialami anak saat usia dini sangat memengaruhi pembentukkan karakter anak di masa yang akan datang (Aqib, 2009: 40-41).

Adanya minat terhadap aktivitas teman-teman dan meningkatnya keinginan yang kuat untuk diterima sebagai anggota suatu kelompok merupakan sebagian tanda dari perkembangan perilaku sosial anak (Mayar, 2013: 460). Perkembangan sosial anak dimulai dari sifat egosentrik, individual, hingga ke arah interaktif komunal (Mansur, 2014: 56). Pada usia 3 tahun anak mulai tumbuh sifat sosialnya, seperti bergaul dengan anak lain dan bermain bersama. Hal ini dapat dilihat ketika anak mulai belajar bersosialisasi saat ia memasuki pendidikan prasekolah (PAUD/TK). Disana anak belajar menyesuaikan diri dengan kelompok teman sebayanya (Aqib, 2009: 41). Perkembangan sosial ini meliputi dua aspek penting, yaitu kompetesi sosial (kemampuan anak beradaptasi dengan lingkungannya secara efektif) dan tanggungjawab sosial (komitmen anak terhadap tugastugasnya, menghargai perbedaan invidual, dan memperhatikan lingkungannya) (Mansur, 2014: 56). 
Emosi adalah perasaan yang ada dalam diri manusia baik senang atau sedih, maupun baik atau buruk. Menurut E. Mulyasa (2012) dalam Ginawati (2017) emosi adalah suatu keadaan atau perasaan yang bergejolak dalam diri seseorang yang disadari dan diungkapkan melalui wajah atau tindakan, yang berfungsi sebagai inner adjustment (penyesuaian dari dalam) terhadap lingkungan untuk mencapai kesejahteraan dan keselamatan individu. Menurut Shapiro (1999) dalam Putra dan Dwilestari (2013: 50) kecerdasan emosional perlu diajarkan sejak dini agar anak tumbuh menjadi seseorang yang dewasa, bertanggung jawab dan mampu menyelesaikan masalah yang dihadapinya. Selain itu, anak yang mempunyai kecerdasan emosional tinggi akan terlihat lebih bahagia, lebih percaya diri dan lebih berprestasi di sekolah.

Kecerdasan emosional memiliki dua peran penting bagi anak-anak (Putra dan Dwilestari, 2013: 50-51). Pertama, peran substansial yang berkaitan dengan bagaimana membuat anak dan kehidupannya menjadi lebih manusiawi. Kedua, peran fungsional yang berkaitan dengan bagaimana menggunakan kecerdasan emosional dalam kehidupan seharihari.

Perkembangan sosial emosional menurut American Academy of Pediatrics (2012) dalam Nurmalitasari (2015) adalah kemapuan anak untuk memiliki pengetahun dalam mengelola dan mengekspresikan emosi secara lengkap baik emosi positif, maupun negatif, mampu berinteraksi dengan anak lainnya atau orang dewasa di sekitarnya, serta aktif belajar dengan mengeksplorasi lingkungan. Perkembangan sosial emosional adalah proses belajar menyesuaikan diri untuk memahami keadaan serta perasaan ketika berinteraksi dengan orang-orang di lingkungannya baik orang tua, saudara, teman sebaya dalam kehidupan sehari-hari. Proses pembelajaran sosial emosional dilakukan dengan mendengar, mengamati dan meniru hal-hal yang dilihatnya.

Menurut Dodge, Colker, dan Heroman (2002) dalam Hildayani (2009: 10.3), pada masa kanak-kanak awal perkembangan sosial emosional hanya seputar proses sosialisasi. Dimana anak belajar mengenai nilai-nilai dan perilaku yang diterimanya dari masyarakat. Pada masa ini, terdapat tiga tujuan perkembangan sosial emosional. Pertama, mencapai pemahaman diri (sense of self) dan berhubungan dengan oranglain. Kedua, bertanggungjawab atas diri sendiri yang meliputi kemampuan mengikuti aturan dan rutinitas, menghargai oranglain, dan mengambil inisiatif. Ketiga, menampilkan perilaku sosial seperti empati, berbagi, dan mengantri dengan tertib. 
Perkembangan sosial emosional erat kaitannya dengan interaksi, baik dengan sesama atau benda-benda lainnya. Jika interaksinya tidak baik, maka pertumbuhan dan perkembangan anak menjadi tidak optimal. Namun kebanyakan orangtua kurang memerhatikan hal tersebut pada anak padahal perkembangan sosial emosional setiap anak berbeda. Dalam hal ini peran pendidik sangat diperlukan untuk memahami perkembangan sosial emosional pada anak agar mereka dapat mengembangkan kemampuannya dengan baik.

Berdasarkan latar belakang di atas, artikel ini bertujuan untuk mengulas bagaimana teori perkembangan sosial emosional, bagaimana reseliensi perkembangan sosial emosional, apa saja karakteristik perkembangan sosial emosional anak usia 4-6 tahun, dan bagaimana kegiatan pembelajaran untuk mengembangkan aspek sosial emosional anak usia 4-6 tahun.

\section{Teori Perkembangan Sosial Erik Erikson}

Erik Erikson lahir Frankfurt, Jerman pada tahun 1902. Ia adalah seorang penganut aliran Psikoanalisis dari Sigmund Freud yang kemudian menjadi neofreudian (psikoanalisa yang didasarkan pada hubungan sosial). Teorinya ini disebut dengan Teori Psikosoaial. Ia berpendapat bahwa setiap individu berjuang melakukan pencarian identitas diridalam tiap tahap kehidupannya. Hal ini dikarenakan identitas merupakan pengertian dan penerimaan, baik untuk diri sendiri maupun masyarakat (Miller, 1983).

Menurut Erikson, masyarakat memiliki peranan yang sangat penting dalam perkembangan psikososial seorang individu. Peranan ini dimulai dari pola asuh orangtua hingga aturan atau budaya masyarakat (Miller, 1983). Berikut ini merupakan tahapan perkembangan psikososial seorang individu (Desiningrum, 2012: 34-35).

1. Kepercayaan vs Ketidakpecyaan (usia 0-1 tahun). Pada tahap ini harus belajar menumbuhkan kepercayaan pada oranglain, contohnya anak kepada ibunya. Jika anak tidak berhasil dalam tahap ini, maka ia akan jadi anak yang mudah takut dan rewel.

2. Otonomi vs Malu dan Ragu-Ragu (usia 1-3 tahun). Pada tahap ini anak mulai belajar kemandirian (otonomi), seperti makan atau minum sendiri. Jika anak tidak berhasil pada tahap ini karena selalu ditegur dengan kasar ketika proses belajar, maka anak akan menjadi pribadi yang pemalu dan selalu ragu-ragu dalam melakukan sesuatu. 
3. Inisiatif vs Rasa Bersalah (usia 3-6 tahun). Pada tahp ini anak mulai memiliki gagasan (inisiatif) berupa ide-ide sederhana. Jika anak mengalami kegagalan pada tahap ini, maka ia akan terus merasa bersalah dan tidakmampu menampilkan dirinya sendiri.

4. Kerja Keras vs Rasa Inferior (usia 6-12 tahun). Pada tahap ini anak mulai mampu berkerja keras untuk menyelesaikan tugas-tugasnya dengan baik. Jika pada tahap ini anak tidak berhasil, maka kedepannya anak akan menjadi pribadi yang rendah diri (minder) dan tidak mampu menjadi pemimpin.

5. Identitas vs Kebingungan Identitas (usia 12-19 tahun). Pada tahap ini individu melakukan pencarian atas jati dirinya (identitasnya). Jika ia gagal pada tahp ini, mak ia akan merasa tidak utuh.

6. Keintiman vs Isolasi (usia 20-25 tahun). Pada tahap ini individu mulai keintiman psikologis dengan oranglain. Jika ia gagal pada tahap ini, maka ia akan merasa kosong dan terisolasi.

7. Generativitas vs Stagnasi (usia 26-64 tahun). Pada tahap ini individu memiliki keinginan untuk menciptakan dan mendidik generasi selanjutnnya. Jika ia tidakberhasil dalam tahap ini, maka ia akan merasa bosan dan tidak berkembang.

8. Integritas vs Keputusan (usia 65 tahun ke atas). Pada tahap ini individu akan menelaah kembali apa saja yg sudah ia lakukan dan ia capai dalam hidupnya. Jika ia berhasil pada tahp ini, maka ia akan mencapai integritas (penerimaan akan kekurarangan diri, sejarah kehidupan, dan memiliki kebijakan), sebaliknya jika ia gagal, maka ia akan merasa menyesal atas apa yg telah terjadi dalam hidupnya.

Berikut tabel tahapan perkembangan psikososial dalam bahasa Inggris (Desiningrum, 2012: 35).

\begin{tabular}{llll}
\hline \multicolumn{1}{c}{ Age } & \multicolumn{1}{c}{ Conflict } & $\begin{array}{c}\text { Resolution or } \\
\text { "Virtue" }\end{array}$ & Culmination in old age \\
\hline Infancy & Basic Trust vs. & Hope & $\begin{array}{l}\text { Appreciation of } \\
\text { interdepedence and } \\
(0-1 \text { year })\end{array}$ \\
& Mistrust & & relatedness. \\
\hline Early childhood & Autonomy vs. & Will & $\begin{array}{l}\text { Acceptance of the cycle of life, } \\
\text { (1-3 year })\end{array}$ \\
& Shame & & $\begin{array}{l}\text { from intergration to } \\
\text { disintergration. }\end{array}$ \\
\hline
\end{tabular}




\begin{tabular}{|c|c|c|c|}
\hline $\begin{array}{l}\text { Play age } \\
\text { (3-6 year) }\end{array}$ & Initiative vs. Guilt & Purpose & Hunor; emphaty; resiliece. \\
\hline $\begin{array}{l}\text { School age } \\
\text { (6-12 year) }\end{array}$ & $\begin{array}{l}\text { Industry vs. } \\
\text { Inferiority }\end{array}$ & Competence & $\begin{array}{l}\text { Humility; acceptance of yhe } \\
\text { course of one's life and } \\
\text { unfulfilled hopes. }\end{array}$ \\
\hline $\begin{array}{l}\text { Adolescence } \\
\text { (12-19 year) }\end{array}$ & $\begin{array}{l}\text { Identity vs. } \\
\text { Confusion }\end{array}$ & Fidelity & $\begin{array}{l}\text { Sense of complexity of life; } \\
\text { merging of sensory, logical } \\
\text { and aesthetic perception. }\end{array}$ \\
\hline $\begin{array}{l}\text { Early adulthood } \\
(20-25 \text { year) }\end{array}$ & $\begin{array}{l}\text { Intimacy vs. } \\
\text { Isolation }\end{array}$ & Love & $\begin{array}{l}\text { Sense of the complexity of } \\
\text { relationships; value of } \\
\text { tenderness and loving freely. }\end{array}$ \\
\hline $\begin{array}{l}\text { Adulthood } \\
\text { (26-64 year) }\end{array}$ & $\begin{array}{l}\text { Generativity vs. } \\
\text { Stagnation }\end{array}$ & Care & $\begin{array}{l}\text { Caritas, caring for others, and } \\
\text { agape, empathy and concern. }\end{array}$ \\
\hline $\begin{array}{l}\text { Old age } \\
\text { (64-death) }\end{array}$ & $\begin{array}{l}\text { Integraty vs. } \\
\text { Despair }\end{array}$ & Wisdom & $\begin{array}{l}\text { Existential identity; a sense of } \\
\text { integrity strong enough to } \\
\text { withstand physical } \\
\text { disintegration. }\end{array}$ \\
\hline
\end{tabular}

\section{Teori Perkembang an Emosional Maslow}

Abraham Maslow lahir di Brooklyn pada tahun 1908 dan meninggal di Rusia pada tahun 1970. Awalnya Maslow mempelajari teori behaviorisme dan melakukan banyak percobaan dalam bidang tersebut. Namun, setelah Pearl Harbour diserang oleh Jepang, ia beralih ke bidang psikologi (Hall, 1985 dalam Hildayani, dkk, 2009: 2. 16). Ia merasa bahwa psikologi hanya memandang manusia dari segi negatifnya, sehingga ia melihat psikologi dari sisi yang lain, yaitu lebih ke sisi positifnya. Maslow berpendapat bahwa manusia tidak hanya harus melawan kesedihan, ketakutan, dan hal negatif lainnya, tetapi manusia juga harus mencari kebahagian dan kesejahteraan. Maslow menyatakan bahwa pada dasarnya manusia itu baik, tidak jahat (We are basically good, no evil). Menurut Maslow ada 4 hal yang harus ditekankan mengenai hal ini.

1. Menusia memiliki struktur psikologis yang beranalagi sperti struktur fisik, yaitu kebutuhan (needs), kapasitas (capacities), dan kecenderungan (tendencies) yang didasari oleh keadaan genetis. 
2. Perkembangan yang sehat diharapkan selalu melibatkan aktualisasi dari karakteristik.

3. Keadaan patologis setiap manusia berasal dari penyangkalan (denial), frustasi (frustration), atau memutar (twisting) keadaan manusia.

4. Manusia memiliki keinginan dan kemampuan aktif untuk mencapai kesehatan mental dalam perkembangan aktualisasi diri.

Menurut Maslow seorang individu dapat berhubungan dengan dunia melalui dua cara, yaitu D-realm atau deficiency (kekurangan) dimana manusia bertahan hidup dengan cara berusaha memenuhi seluruh kebutuhan dasarnya. Setelah kebutuhan dasarnya terpenuhi, maka manusia akan beranjak ke tahap B-realm atau being (menjadi), dimana manusia memiliki motivasi untuk mencari aktuailisasi dirinya dan pengayaan dari keberadaannya. Maslow mencetuskan sebuah teori yang berkaitan dengan motivasi manusia dalam memenuhi kebutuhannya. Teori ini disebut sebagai Hierarki Kebutuhan Maslow, yang meliputi:

1. Kebutuhan fisiologis, yaitu kebutuhan fisik yang paling dasar seperti rasa lapar, haus, dan lelah.

2. Kebutuhan akan rasa aman, yaitu kebutuhan akan rasa keselamatan, kestabilan, proteksi, struktur, keteraturan, hukum, batasan, dan bebas dari rasa takut.

3. Kebutuhan memiliki dan cinta, yaitu kebutuhan memiliki hubungan yang harmonis dengan oranglain, seperti keluarga, pasangan, anak, dan teman.

4. Kebutuhan rasa percaya diri, yaitu kebutuhan akan perasaan kuat, menguasai sesuatu, kompetensi, dan kemandirian. Juga kebutuhan akan perasaan dihormati oleh oranglain, status, ketenaran, dominansi menjadi orang penting, serta harga diri dan penghargaan.

5. Kebutuhan aktualisasi diri dan metaneeds, yaitu kebutuhan untuk mengaktualisasikan diri dengan mengembangkan diri dan melakukan sesuatu yang dikuasai. Contohnya adalah seorang musisi yang menciptakan lagu dan seorang pengusaha yang sukses. Kebutuhan aktualisasi diri ini memayungi metaneeds, dimana sebagian metaneeds ini merupakan merupakan kebutuhan dasar yang harus dipenuhi. Sebagai contoh kebutuhan akan keadilan, keteraturan, kebebasan melakukan sesuatu dan berpendapat, serta mencari informasi dan membela diri sendiri. Sedangkan sebagian lainnya adalah kebutuhan yang lebih mengacu pada keindaan, seperti kecantikan dan kesederhanaan. 


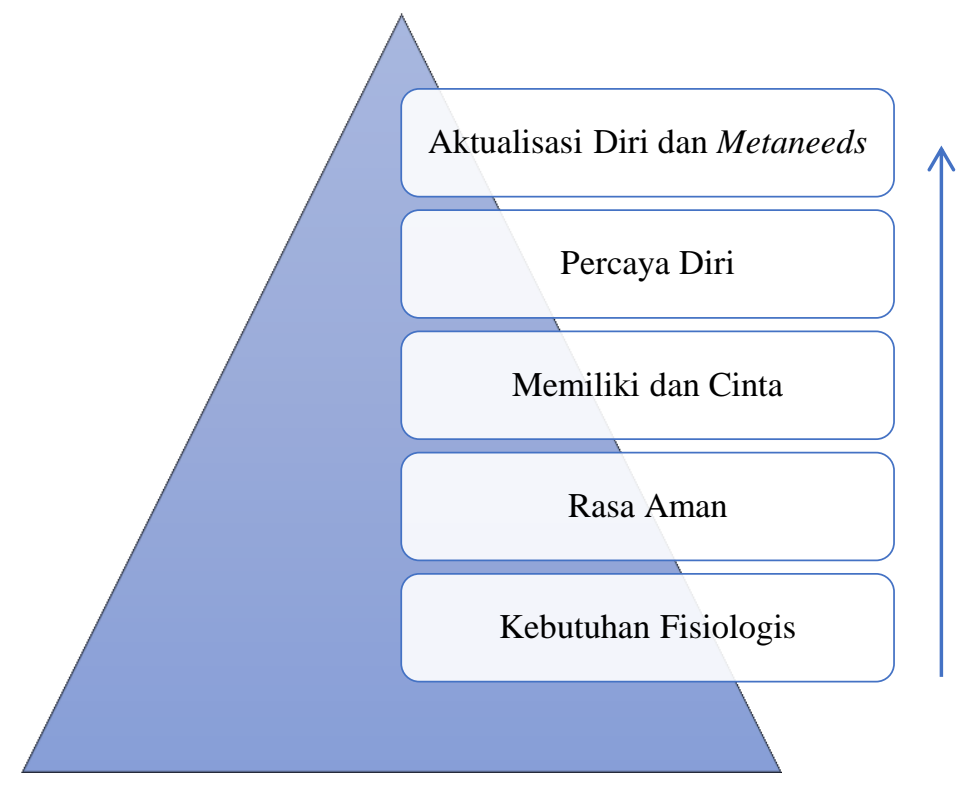

\section{Resiliensi}

Anak akan mengalami berbagai tantangan yang menuntut mereka untuk mempunyai kemampuan untuk mengatasi tantangan-tantangan hidup tersebut. Kemampuan inilah yang disebut dengan resiliensi. Resiliensi ini berperan sebagai proses pendampingan untuk anak dalam mempersiapkan diri agar mampu menghadapi tantangan dan kerentanan serta terhindar dari kemunduran, sehingga dapat sukses dalam segala bidang kehidupan di masa yang akan datang. Pendidik harus paham mengenai resiliensi pada anak, agar dapat membuat anak memiliki tingkat resiliensi yang baik (Patilima, 2012: 177).

Menurut Reivich, Shatte, dan Norman dalam Helton dan Smith (2004) resiliensi merupakan kemampuan seseorang untuk bertahan, bangkit, dan menyesuaikan dengan kondisi yang sulit. Dalam istilah Psikologi, resiliensi adalah kemampuan seorang individu untuk cepat pulih dari perubahan, rasa sakit, kemalangan, atau kesulitan (Widuri, 2012: 149). Jadi, resiliensi adalah suatu kemampuan individu untuk berjuang melawan keadaan yang tidak diinginkan dan berjuang untuk bangkit kembali setelah terkena keadaan yang tidak diinginkan itu.

Resiliensi seorang individu dipengaruhi oleh faktor internal yang meliputi kemampuan kognitif, gender, dan keterikatan individu dengan budaya. Sedangkan faktor eksternalnya meliputi, keluarga dan komunitas atau lingkungan. Seorang individu yang resilien, akan mampu mengontrol emosi, tingkah laku, dan atensi dalam menghadapi masalah. Sebaliknya, individu yang mengalami kesulitan dalam mengendalikan emosi 
akan sulit beradaptasi, sulit menjalin relasi dengan orang lain, dan sulit mempertahankan hubungan yang telah dibangun dengan oranglain(Widuri, 2012: 149).

Menurut Rojas (2015) dalam Utami dan Helmi (2017: 54-55) meningkatkan resiliensi merupakan tugas yang sangat penting karena dapat memberikan pengalamanbagi individu dalam menghadapi tantangan dan kesulitan hidup. Dengan meningkatkan resiliensi, seorang individu dapat mengembangkan berbagai keterampilan hidup seperti bagaimana berkomunikasi, kemampuan realistik dalam membuat rencana hidup dan mampu mengambil keputusan yang tepat untuk hidupnya. Karakteristik individu yang memiliki resiliensi tinggi menurut Murphey (2013) dalam Utami dan Helmi (2017: 54) adalah mereka yang easygoing dan mudah bersosialisasi, memiliki ketrampilan berpikir yang baik, memiliki orang yang medukung disekitarnya, memiliki bakat, percaya diri dalam mengambil keputusan, serta memiliki spiritualitas.

\section{Karakteristik Perkembangan Sosial-Emosional Anak Usia 4-6 Tahun}

Menurut Seomariati (2005) dalam Nurjannah (2017: 53) karakteristik bersosialisasi anak TK diantaranya adalah:

1. Anak memiliki satu atau dua sahabat tetapi sahabat ini mudah berganti.

2. Kelompok bermain cenderung kecil dan tidak terorganisir secara baik, sehingga mudah berganti-ganti.

3. Anak lebih mudah bermain bersebelahan dengan teman yang lebih besar.

4. Perselisihan sering terjadi namun hanya sebentar kemudian mereka kembali baikan. Berdasarkan karakteristik tersebut, perkembangan sosial anak masih sering pilihpilih teman dan hanya memiliki salah satu teman untuk bermain selain itu anak juga masih sering bertengkar karena memperebutkan mainan dan seseorang yang dianggap miliknya sendiri. Menurut Soemariati Patmonodewo (2003: 27) dalam Nurjannah (2017: 54) anak TK cenderung mengekspresikan emosinya dengan bebas dan terbuka. Sikap marah sering diperlihatkan anak pada usia tersebut. Selain itu, anak juga sering merasa iri kepada temannya dan memperebutkan perhatian guru.

Perkembangan sosial mulai berjalan pada usia 4-6 tahun, hal ini tampak dari kemampuan mereka dalam melakukan sesuatu secara berkelompok. Karakteristik pada tahap ini adalah anak mulai mengetahui aturan-aturan disekitarnya, kemudian mereka mulai tunduk pada aturan tersebut, lalu anak mulai menyadari pentingnya hak orang lain, dan mereka mulai dapat bermain dengan teman sebayanya (Nurmalitasari,2015: 105). 
Karakteristik emosi pada anak antara lain: berlangsung singkat dan berakhir tibatiba, terlihat lebih hebat atau kuat, bersifat sementara, lebih sering terjadi, dapat diketahui dengan jelas dari tingkah lakunya, dan reaksi mencerminkan individualitas. Santrock (2007) dalam Nurmalitasari (2015: 106), perkembangan emosi pada anak ditandai dengan munculnya emosi evaluative yang didasari oleh rasa bangga, malu, dan rasa bersalah, dimana kemunculan emosi ini menunjukkan bahwa anak sudah mulai memahami dan menggunkan norma sosial untuk menilai perilaku mereka.

\section{Kegiatan Pembelajaran yang Sesuai untuk Mengembangkan Aspek Sosial-Emosional Anak Usia 4-6 Tahun}

Kecerdasan sosial-emosional pada anak tidak dimiliki secara alami tetapi harus ditumbuhkan dan dikembangkan oleh orangtua maupun oleh pendidik PAUD. Dalam mengembangankan sosial-emosional anak diperlukan metode yang bisa digunakan untuk mengembangkan aspek tersebut, berikut beberapa metode yang dapat digunakan.

\section{Keteladanan}

Pembelajaran dengan melalui keteladanan adalah pembelajaran melalui contohcpntoh yang baik, dapat diterima oleh masyarakat, dan sesuai dengan standar dan sistem nilai yang berlaku. Metode ini efektif diterapkan pada anak melalui proses pencontohan dan peniruan. Kegiatan keteladanan dapat ditularkan kepada anak usia dini untuk mengembangkan sosial-emosional antara lain sebagai berikut: (Nurjannah, 2017: 59)

a. keteladanan dalam beribadah, seperti adab dalam berdoa dan solat.

b. Keteladanan yang berhubungan dengan oranglain, seperti cara menyapa, cara meminta, cara berkomunikasi, dan tata krama.

c. Keteladanan dalam bekerja dnmenyelesaikan masalah, seperti bersabar, bersemangat, dan displin.

d. Teladan dalam berpakaian dab berbusana, seperti berpakaian ke sekolah, berpakaian melayat orang yang meninggal, dan berpaaian beribadah.

e. Teladan gaya hidup, yaitu tidak boros, sederhana, suka menabung, dan lain-lain.

f. Teladan cara belajar, seperti pemanfaatan waktu belajar, adab belajar, dan sebagainya.

g. Teladan dalam menyikapi lingkungan, seperti membuang sampah pada tempatnya, membersihkan kamar atau kelas sendiri, dan sebagainya. 
Selain dari contoh-contoh di atas masih banyak teladan lain yang bisa dilakukan, sesuai dengan perkembangan budaya dan kebutuhannya. Pendekatan ini sangat penting karena anak memiliki daya imitasi yang tinggi.

\section{Metode Mendongeng atau Bercerita}

Mendongeng adalah suatu kegiatan yang bersifat professional, karena membutuhkan keahlian khusus, seperti mengatur gaya dan intonasi ketika bercerita agar membuat anak tertarik untuk mendengarkan dan memahami cerita atau dongeng yang disampaikan. Nilai yang terkandung dalam dongeng pun harus di bungkus dengan sebaik mungkin, baru setelah selesai mendongengkan pendidik menjelasakan nilai tersebut (Santoso, 2011: 4.22-4.23). Cerita yang disampaikan dengan baik akan mampu mengajak anak memasuki sebuah "dunia baru" dan membuat membangkitkan kehidupan yang bary dab menambah nilai seni anak (Efendi, 2006: 4). Melalui kegiatan mendongeng ini pendidik dapat membentuk sikap anak melalui nilai, pesan, atau sikap yang terkandung dalam dongeng yang disampaikan(Santoso, 2011: 4.22-4.23). Selain itu juga, melalui pengenalan dan pemahaman nilai-nilai yang ada dalam kegiatan mendongeng ini, anak akan terdorong untuk terus berinteraksi dengan lingkungan dan oranglain (Efendi, 2006: $3)$.

\section{Bermain Kooperatif}

Menurut Nugraha (2004) dalam Wardany, Jaya, dan Anggraini (2016) bermain kooperatif adalah permainan yang dilakukan oleh sekolompok anak, dimana setiap anak mendapatkan peran dan tugasnya masing-masing yang harus dilakukan untuk mencapai tujuan bersama. Hal ini sejalan dengan hasil penelitian Kibtiyah (2006) dalam Wardany, dkk (2016), efek dari bermain kooperatif menunjukkan bahwa anak yang tumbuh dengan sering bermain, secara sosial ia lebih aktif, lebih kreatif, lebih kaya akan kosa kata, lebih lancar dalam berbicara, dan lebih bahagia dalam menjalankan tugas-tugasnya jika dibandingkan dengan anak yang tidak bermain. Kemudian menurut hasil penelitian Kartika (2015) dalam Wardany, dkk (2016), bermain kooperatif dapat meningkatkan perilaku kerjasama dan membantu anak untuk tidak berperilaku agresif. Selain itu, bermain jenis ini dapat meningkatkan rasa penghargaan pada teman sebaya, pada diri sendiri, dan ketrampulan sosial lainnya.

\section{Bermain Pura-Pura atau Bermain Peran}

Kegiatan bermain peran ini dapat dilakukan sejak anak berusia 3 tahun. Kegiatan bermain ini melibatkan unsur imajinasi dan daya imitasi pada perilaku orang dewasa. 
Contohnya, bermain sekolah-sekolahan, pasar-pasaran, dan dokter-dokteran. Dalam permainan ini anak menggunaka imajinasi untuk menghasilkan gagasannya sendiri, seperti sebatang ranting yang dianggap sebagai sebuah pedang. Imajinasi anak juga menggambarkan keinginan, perasaan, dan pandangan anak terhadap lingkungan sekitarnya (Mulyani, 2014: 143).

\section{Outbound}

Outbound merupakan suatu kegiatan bermain yang dilakukan di alam terbuka dengan berdasarkan prinsip experiential learning (belajar melalui pengalaman langsung) yang bersifat kreatif, edukatif, serta rekreatif, dan petualangan dijadikan sebagai media penyampaian materi dengan anak dilibatkan dalam seluruh kegiatan yang dilakukan (Isbayani, Sulastri, dan Tirtayani (2015) dalam Istiqomah, Lathif, dan Khutobah (2016: 20)). Melalui kegiatan ini anak belajar mengenali kemampuan dan kelemahan dirinya sendiri, serta tertantang untuk mengembangkan kemampuan yang dimilkinya (Istiqomah,dkk, 2016: 20). Jenis permainan outbound yang dapat dipilih diantaranya adalah permainan halang rintang, estafet tongkat, dan moving water.

\section{Simpulan}

Perkembangan sosial emosional adalah proses belajar menyesuaikan diri untuk memahami keadaan serta perasaan ketika berinteraksi dengan orang-orang di lingkungannya baik orang tua, saudara, teman sebaya dalam kehidupan sehari-hari. Perkembangan sosial emosional erat kaitannya dengan interaksi, baik dengan sesama atau benda-benda lainnya. Jika interaksinya tidak baik, maka pertumbuhan dan perkembangan anak menjadi tidak optimal. Resiliensi adalah kemampuan individu dalam mengatsi tantangan hidup serta mempertahankan kesehatan dan energi yang baik sehingga dapat melanjutkan hidup secara sehat. Resiliensi anak adalah proses pendampingan oleh pendidik untuk mempersiapkan anak usia dini agar mampu menghadapi kerentanan dan tantangan, terhindar dari kemunduran, sehingga sukses dalam segala bidang kehidupan di masa depan. Perkembangan sosial anak masih sering pilih-pilih teman dan hanya memiliki salah satu teman untuk bermain selain itu anak juga masih sering bertengkar karena memperebutkan mainan dan seseorang yang dianggap miliknya sendiri. Metode yang dapat digunakan untuk mengembangkan kecerdasan sosial-emosional anak diantaranya adalah dengan bermain dan keteladanan yang dilakukan oleh orangtua maupun pendidik PAUD. 


\section{DAFTAR PUSTAKA}

Anwar, dan Ahmad, Arsyad. 2016. Pendidikan Anak Dini Usia: Panduan Bagi Ibu dan calon Ibu. Bandung: CV Alfabeta.

Aqib, Zainal. 2009. Belajar dan Pembelajaran di Taman Kanak-Kanak. Bandung: CV. Yrama Widya.

Desiningrum, Dinie Ratri. 2012. Psikologi Perkembangan I. Semarang: Universitas Diponegoro.

Efendi, Anwar. 2006. Mengembangkan Kecerdasan Emosional Anak melalui Kebiasaan Bercerita (Dongeng). Jurnal Pemikiran Alternatif Kependidikan (Insania). Vol. 11 (3), hlm 328-336.

Ginawati, Dewi. 2017. Meningkatkan Perkembangan Sosial Emosional Anak Usia Dini melalui Metode Bermain Peran (Role Playing). STKIP Siliwangi Bandung.

Helton, L. R. \& Smith, M. K. (2004). Mental Health Practice with Children and Youth. New York: The Hawort Social Work Practice Press.

Hildayani, Rini, dkk. 2009. Psikologi Perkembangan Anak. Jakarta: Universitas Terbuka.

Istiqomah, N., Lathif, M. A., dan Khutobah. 2016. Peningkatan Perkembangan Sosial dan Emosional melalui Kegiatan Outbound pada Anak Kelompok B di TK AsySyafa'ah Jember Tahun Pelajaran 2015/2016. Jurnal Edukasi UNEJ. Vol. 3 (2), hlm. 19-21.

Mansur. 2005. Pendidikan Anak Usia Dini dalam Islam. Yogyakarta: Pustaka Pelajar.

Mayar, Farida. 2013. Perkembangan Sosial Anak Usia Dini sebagai Bibit untuk Masa Depan Bangsa. Jurnal Al-Ta'lim. Vol. 1 (6), hlm 459-464.

Miller, P. H. 1983. Theoris of Development Psychology. New York: W. Freeman and Company.

Mulyani, Novi. 2014. Upaya Meningkatkan Perkembangan Sosial Emosional Anak Usia Dini. Raushan Fikr. Vol. 3 (2), hlm. 133-147.

Musringati. 2017. Mengembangkan Kemampuan Sosial Emosional Anak Usia Dini pada Kelompok B melalui Metode Bercerita di TK Al Ikhlas. STKIP Siliwangi Bandung.

Nurjannah. 2017. Mengembangkan Kecerdasan Sosial Emosional Anak Usia Dini melalui Keteladanan. Jurnal Bimbingan Konseling dan Dakwah Islam. Vol.14 (1), hlm. 5061.

Nurmalitasari, Femmi. 2015. Perkembangan Sosial Emosi pada Anak Usia Prasekolah. Buletin Psikologi .Vol.23 (2), hlm. 103-111.

Patilima, Hamid. 2013. Peran pendidik PAUD dalam Membangun Resiliensi Anak. Jurnal Pendidikan Usia Dini. Vol.7 (1), hlm 173-194.

Putra, Nusa dan Ninin Dwilestari. 2013. Penelitian Kualitatif Pendidikan Anak Usia Dini. Jakarta: PT Raja Grafindo Persada.

Santoso, Soegeng. 2011. Dasar-Dasar Pendidikan TK. Jakarta: Universitas Terbuka.

Trianto. 2011. Desain Pengembangan Pembelajaran Tematik bagi Anak Usia Dini TK/RA \& Anak Usia Kelas Awal SD/MI. Jakarta: Kencana.

Utami, C. T., dan Helmi, A. F. 2017. Self-Efficacy dan Resiliensi: Sebuah Tinjauan MetaAnalisis. Buletin Psikologi. Vol. 25 (1), hlm. 54-65.

Wahyuni, S., Syukri, M., dan Miranda, D. 2015. Peningkatan Perkembangan Sosial Emosional melalui Pemberian Tugas Kelompok pada Anak Usia 5-6 Tahun. Universitas Tanjungpura, Pontianak. Hlm. 1-15. 
Wardany, M. P., Jaya, M. Thoha B. S., dan Anggraini, G. F. 2016. Aktivitas Bermain Kooperatif Meningkatkan Perkembangan Sosial-Emosional Anak. FKIP Universitas Lampung. Hlm. 1-9.

Widuri, Erlina Listyanti. 2012. Regulasi Emosi dan Resiliense pada Mahasiswa Tahun Pertama. Humanitas. Vol. 9 (2), hlm 148-156. 